\title{
Effect of Micronutrient Application on Vegetative Growth and Bulb Yield Attributes of Rabi Onion (Allium cepa L.)
}

\author{
Pooja Biswas ${ }^{1}$, Shreya Das ${ }^{2 *}$, Aloke Bar ${ }^{3}$, Tapan Kumar Maity ${ }^{4}$ \\ and Amit Ranjan Mandal $^{4}$
}

${ }^{1}$ Department of Vegetable Science, ${ }^{2}$ Department of Agricultural Chemistry \& Soil Science, ${ }^{3}$ Department of Plantation, Spices, Medicinal and Aromatic Plants, ${ }^{4}$ Department of Vegetable Science, Bidhan Chandra Krishi Viswavidyalaya, Mohanpur, West Bengal, India-741 252

*Corresponding author

\section{A B S T R A C T}

Keywords

Micronutrients, Foliar application, Onion, Growth, Yield

\section{Article Info}

Accepted:

05 February 2020

Available Online:

10 March 2020
An experiment was conducted to evaluate the efficacy of micronutrients on performance of Onion cv. Sukhsagar at Nadia, West Bengal during 20172018.The experiment was laid out in RBD having four replication with six treatments each having FYM @ $20 \mathrm{t} \mathrm{ha}^{-1}$, viz. $\mathrm{T}_{1}$ (RDF + soil application of Zinc Sulphate @ $\left.10.0 \mathrm{~kg} \mathrm{ha}^{-1}\right), \mathrm{T}_{2}$ (RDF+ foliar application of Zinc Sulphate @ 0.5\% at $30 \& 45$ days after planting (DAP), $\mathrm{T}_{3}(\mathrm{RDF}+$ soil application of Borax @ $10.0 \mathrm{~kg}$ $\left.\mathrm{ha}^{-1}\right), \mathrm{T}_{4}$ (RDF+ foliar application of Borax @ $0.25 \%$ at $\left.30 \& 45 \mathrm{DAP}\right), \mathrm{T}_{5}$ (RDF+ Foliar application of Micronutrient Mixture i.e. iron- $2.5 \%$, boron- $0.5 \%$,zinc -3\%, copper -1\% and manganese- $1 \%$ @ $0.5 \%$ at $30 \& 45 \mathrm{DAP}$ ) and $\mathrm{T}_{6}$ (control). Highest plant height $(63.72 \mathrm{~cm})$, number of leaves/plant (12.71), polar diameter $(58.62$ $\mathrm{mm})$, equatorial diameter $(46.88 \mathrm{~mm})$, average weight $(61.72 \mathrm{~g})$ of bulb, yield ha ${ }^{-1}$ $(266.80 \mathrm{q})$ and highest \% (29.82) of A grade bulbs, were recorded with $\mathrm{T}_{5}$ followed by $\mathrm{T}_{4}$.Hence, it is concluded foliar application of micronutrient mixture @ $0.25 \%$ followed by borax @ $0.5 \%$ at 30 and 45 DAP is better in respect of bulb growth and yield.

\section{Introduction}

Onion (Allium cepa L.) belonging to the family Alliaceae, is one of the most important and popular vegetable and spice crops cultivated worldwide (Mishra et al., 2013). It is famous for its characteristics flavour and it is widely used to increase the taste of foods like gravies, soups, stew stuffing, fried fish and meat (Rashid et al., 2016). Onion is consumed as a vegetable and condiment. The edible part of Onion is green leaves, immature and mature bulbs. It is eaten raw or used in vegetable preparations. It is an indispensable item in every kitchen and used to enhance flavour of different recipes. It is hence known as "Queen of Kitchen". It is a rich source of major minerals like calcium $(180 \mathrm{mg} / 100 \mathrm{~g})$, 
phosphorus $(50 \mathrm{mg} / 100 \mathrm{~g})$, iron $(0.7 \mathrm{mg})$, carbohydrates $(11.0 \mathrm{~g})$, protein $(1.2 \mathrm{~g})$, dietary fibre $(0.6 \mathrm{~g})$, vitamin $\mathrm{C}(11 \mathrm{mg})$ and minerals $(0.4 \mathrm{~g})$.Onion has strong flavour due to presence of sulphur containing compound in very small quantity (about $0.005 \%$ ) in the form of volatile oil allyl propyl disulphide $\left(\mathrm{C}_{6} \mathrm{H}_{12} \mathrm{O}_{2}\right)$ responsible for distinctive smell and pungency acts as gastric, stimulant and promotes digestion. India ranks first in area \& second in production. Maharashtra, Madhya Pradesh, Karnataka, Gujarat, Bihar, Andhra Pradesh, Rajasthan, Haryana \& Tamil Nadu are the major onion growing states (Pramanik et al., 2018).In West Bengal, onion is grown mostly in Hooghly, Murshidabad, Nadia and North 24 Parganas districts. The total area under onion in West Bengal was 29 thousand ha with production and productivity of 465.45 thousand MT and 16.05 MT/ha, respectively (Anon, 2017). In the foreign exchange point of view, onion ranks first among the vegetables.

Proper plant nutrition is one of the most important factors in improving the as quantity well as quality of plant products. Micronutrients are needed by the plants in minor quantities but they are involved indifferent metabolic processes as well as cellular functions within the plants. In general, micronutrients play an active role in the plant metabolic process starting from cell wall development to respiration, photosynthesis, chlorophyll formation, enzyme activity, nitrogen fixation etc. (Ballabh et al., 2013). Boron and zinc are the most important micro-nutrients which are essential for cell division, nitrogen and carbohydrate metabolism and water relation in plant growth (Brady, 1990). The functional role of $\mathrm{Zn}$ includes auxin metabolism, influence on the activities of dehydrogenase, carbonic anhydrate enzymes, synthesis of cytochrome and stabilization or ribosomal fractions (Tisdale et al., 1985). Boron is an essential micronutrient required for normal plant growth and development. It is a very sensitive element and plants differ widely in their requirements but the ranges of deficiency and toxicity are narrow. It is necessary for normal cell division, nitrogen metabolism and protein formation. It is essential for proper cell wall formation. Application of boron can increase bulb size and yield of onion (Smriti et al., 2002).Deficiency of micronutrients during the last three decades has grown in both, magnitude and extent. This has become a major constraint to production and productivity of vegetables in general and onion in particular. Bhonde et al., (1995) evaluated the effect of zinc, copper and boron on onion crop. Bulb size and yield as well as quality of bulb enhanced when micronutrients were applied in combinations instead of their single application. Foliar application of micronutrients during active crop growth stage was successfully used for correcting their deficits and improving the mineral status of the plants as well as increasing the crop yield and quality (Kolota and Osinska, 2001).Keeping this background, a field experiment was conducted at new alluvial soils of West Bengal during Rabi season of 2017-2018to study about the effect of micronutrients on vegetative growth and bulb yield attributes in onion.

\section{Materials and Methods}

\section{Site description}

The field experiment was conducted at " $\mathrm{C}$ " Block Farm, Bidhan Chandra Krishi Viswavidyalaya, Kalyani, Nadia, West Bengal, India during the period between November 2017 and March2018. The farm is situated at $23.5^{\circ} \mathrm{N}$ latitude and $89^{\circ} \mathrm{E}$ longitude with an average altitude of $9.75 \mathrm{~m}$ above the mean sea level. Topographic situation of the experimental site belongs to Gangetic new 
alluvial plains of West Bengal. All laboratory experiments had been conducted in the laboratories of Department of Vegetable Crops, Bidhan Chandra Krishi Viswavidyalaya, Mohanpur and Department of Agricultural Chemistry and Soil Science, Kalyani, Nadia, West Bengal.

\section{Experimental details}

The experiment was laid out in a RBD (Randomized Block Design) with six treatments and four replication. Experimental field was divided into four blocks and each of them was further subdivided into six plots. There were total 24 plots in the experiment. The crop was planted in a plot (size $2 \mathrm{~m} \times$ $1.5 \mathrm{~m}$ ) at a spacing of $15 \mathrm{~cm} \times 10 \mathrm{~cm}$. Before fertilizer application, random soil samples were taken from the experimental field and were analysed.

The soils were non-saline (EC $0.11 \mathrm{dS} / \mathrm{m}$ ), sandy-loam in texture, slightly acidic in reaction $(\mathrm{pH}$ 6.6) and medium to low in organic carbon $(0.66 \%)$ with good drainage facilities. The treatments includes $_{1}$ (recommended 100:60:80:40 NPKS kg ha ${ }^{-1}+$ FYM @ $20 \mathrm{t} \mathrm{ha}^{-1}+$ soil application of Zinc Sulphate@10.0 kg ha ${ }^{-1}$ ), $\mathrm{T}_{2}$ (recommended 100:60:80:40 NPKS kg ha ${ }^{-1}$ + FYM @ 20 t $\mathrm{ha}^{-1}+$ foliar application of Zinc Sulphate @ $0.5 \%$ at $30 \& 45$ days after planting (DAP)), $\mathrm{T}_{3}$ (recommended 100:60:80:40 NPK kg ha ${ }^{-1}$ +FYM@20 t ha ${ }^{-1}$ + soil application of Borax@10.0 kg ha ${ }^{-1}$ ), $\mathrm{T}_{4}$ (recommended 100:60:80:40 NPK kg ha-1 +FYM @ $20 \mathrm{t} \mathrm{ha}^{-1}$ + foliar application of Borax @ $0.25 \%$ at 30 \& 45 DAP), $\mathrm{T}_{5}$ (recommended 100:60:80:40 NPK kg ha ${ }^{-1}+$ FYM @ $20 \mathrm{t} \mathrm{ha}^{-1}+$ Foliar application of Micronutrient Mixture i.e. iron$2.5 \%$, boron- $0.5 \%$, zinc $-3 \%$, copper $-1 \%$ and manganese-1\% @ $0.5 \%$ at $30 \& 45 \mathrm{DAP}$ ) and $\mathrm{T}_{6}$ (control). Ten plants were selected from each plot randomly as a unit for observation on growth aspect and yield attributes.

\section{Soil analysis}

Representative soil samples of the experimental field were collected randomly up to the depth of $0-15 \mathrm{~cm}$. The soil samples were air dried, ground well in wooden mortar and pestle and sieved through $2 \mathrm{~mm}$ sieve. The soil samples were analyzed from each treatment separately for soil available N, P, K, $\mathrm{S}, \mathrm{Zn}$ and $\mathrm{B}$ before planting and after harvest of crop according to standard methods as mentioned in Table 1.

\section{Results and Discussion}

\section{Plant growth parameters}

In the present field experiment, foliar application of micronutrients exerted a significant influence on plant growth parameters in onion viz. plant height and number of leaves/plant.

\section{Plant height}

The results show that at 30 DAT, the significant highest plant height $(35.99 \mathrm{~cm})$ was recorded with soil application of Zinc sulphate@10 kg/ha $\left(\mathrm{T}_{1}\right)$. Foliar application of Borax @ $0.25 \%\left(\mathrm{~T}_{4}\right)(30.96 \mathrm{~cm})$ was statistically at par with $(30.19 \mathrm{~cm})$ foliar application of micronutrient mixture @ $0.5 \%$ (Fe - $2.5 \%, \mathrm{~B}-0.5 \%, \mathrm{Zn}-3 \%, \mathrm{Cu}-1 \%$ and $\mathrm{Mn}-1 \%)\left(\mathrm{T}_{5}\right)$. At 60 DAT, foliar application of Borax @ $0.25 \%\left(\mathrm{~T}_{4}\right)$ had recorded significantly highest plant height $(60.17 \mathrm{~cm})$ and it was at par $(59.46 \mathrm{~cm})$ with $\mathrm{T}_{5}$, i.e. foliar application of micronutrient mixture @ $0.5 \%$ (Fe - $2.5 \%, \mathrm{~B}-0.5 \%, \mathrm{Zn}-3 \%, \mathrm{Cu}-1 \%$ and Mn - $1 \%$ ).At 90 DAT, the highest plant height of $63.72 \mathrm{~cm}$ was recorded with $\mathrm{T}_{5}$, i.e. foliar application of micronutrient mixture @ $0.5 \%$ (Fe - $2.5 \%, \mathrm{~B}-0.5 \%, \mathrm{Zn}-3 \%, \mathrm{Cu}-1$ $\%$ and $\mathrm{Mn}-1 \%)$ followed by $(60.45 \mathrm{~cm})$ foliar application of Borax @ $0.25 \%\left(\mathrm{~T}_{4}\right)$. However, $\mathrm{T}_{6}$ (control) had recorded the 
lowest plant height of $27.02 \mathrm{~cm}, 50.26 \mathrm{~cm}$ and $51.41 \mathrm{~cm}$ at 30, 60 and 90 DAT respectively (Table 2).

The increase in plant height due to application of micronutrient mixture; zinc as well as boron alone observed in the present investigation attributed to their role in cell division and auxin synthesis in the active sinks which would have led to higher transport and accumulation of photosynthates in foliage. Similar findings of better efficacy of boron has been reported by Dake et al., (2011) while by zinc application reported by Maurya et al., (2018) and Aske et al., (2017) in onion. Similarly, better efficacy of micronutrient mixture was reported by Goyal et al., (2017) in onion.

\section{Number of leaves per plant}

The results show that at 30 DAT, soil application of Borax $\left(\mathrm{T}_{3}\right)$ had produced significantly maximum number of leaves/plant (4.34), which was closely followed by (4.25 leaves/plant) soil application of Zinc sulphate @ $10 \mathrm{~kg} / \mathrm{ha}\left(\mathrm{T}_{1}\right)$ and was statistically at par. Foliar application of micronutrient mixture @ $0.5 \%$ (Fe - 2.5 $\%, \mathrm{~B}-0.5 \%, \mathrm{Zn}-3 \%, \mathrm{Cu}-1 \%$ and $\mathrm{Mn}-1$ \%) $\left(\mathrm{T}_{5}\right)$ (3.49 leaves/plant) was at par with foliar application of Zinc sulphate@ $0.5 \%$ $\left(\mathrm{T}_{1}\right)$ (3.37 leaves/plant) and Borax @ $0.25 \%$ $\left(\mathrm{T}_{4}\right)$ (3.61).At $60 \mathrm{DAT}$, foliar application of micronutrient mixture @ $0.5 \%(\mathrm{Fe}-2.5 \%$, B $-0.5 \%, \mathrm{Zn}-3 \%, \mathrm{Cu}-1 \%$ and $\mathrm{Mn}-1 \%)\left(\mathrm{T}_{5}\right)$ had recorded significantly maximum number of leaves/plant (9.19).At 90 DAT, foliar application of micronutrient mixture @ $0.5 \%$ (Fe - $2.5 \%, \mathrm{~B}-0.5 \%, \mathrm{Zn}-3 \%, \mathrm{Cu}-1 \%$ and $\mathrm{Mn}-1 \%)\left(\mathrm{T}_{5}\right)$ had recorded significantly maximum number of leaves/plant (12.71). However, $\mathrm{T}_{6}$ (control) had recorded the lowest numbers of leaves/plant of 3.2, 6.46and 10.70 at 30, 60 and 90 DAT respectively (Table 2).
The application of micronutrients in onion increased the production of more leaves/plant than control. This might be due to their role in cell division, meristematic activity of plant tissue and expansion of cell (Patil et al., 2009). Similar result was reported by Paul et al., (2007) and Acharya et al., (2015) in onion crop. Similarly, better efficacy of micronutrient mixture was reported by Smriti et al., (2002); Ballabh et al., (2013) and Goyal et al., (2017) in onion crop.

\section{Bulb parameters}

\section{Neck Thickness of Bulb}

The result revealed that foliar application of Zinc sulphate@0.5\% ( $\left.\mathrm{T}_{2}\right)$ produced bulbs with relatively thin neck thickness of $0.60 \mathrm{~cm}$ closely followed $(0.66 \mathrm{~cm})$ by foliar application of micronutrient mixture @ $0.5 \%$ (Fe - $2.5 \%, \mathrm{~B}-0.5 \%, \mathrm{Zn}-3 \%, \mathrm{Cu}-1 \%$ and $\mathrm{Mn}-1 \%)\left(\mathrm{T}_{5}\right)$. However, $\mathrm{T}_{6}$ (control) produced bulbs with maximum neck thickness of $0.92 \mathrm{~cm}$ (Table 3).Thin and compact neck is ideal for onion, which improve the storage life of bulbs. Mean neck thickness of the plants increased slowly in first month, rapidly in 30-60 days period and slowly reduced between 60-90 days and rapidly reduced after 90 days because of maturity. The application of zinc might have reduced the moisture content and reduced the bulb neck thickness (Maurya et al., 2018) in onion. Manna (2013) also observed significant improvement in bulb neck thickness in onion by application of boron.

\section{Polar diameter of bulbs}

Polar diameter of bulb differed significantly due to different treatments (Table 3). The maximum polar diameter $(58.62 \mathrm{~mm})$ was observed with foliar application of micronutrient mixture @ $0.5 \%$ (Fe - $2.5 \%$, B - $0.5 \%, \mathrm{Zn}-3 \%, \mathrm{Cu}-1 \%$ and $\mathrm{Mn}-1 \%$ ) 
$\left(\mathrm{T}_{5}\right)$. The result also showed that foliar application of micronutrient both alone $\left(\mathrm{T}_{2}\right.$ and $\mathrm{T}_{4}$ ) or in combinations $\left(\mathrm{T}_{5}\right)$ significantly increased the polar diameter of onion bulbs as compared to soil application of micronutrients @ $10 \mathrm{~kg} / \mathrm{ha} \quad\left(\mathrm{T}_{1}\right.$ and $\left.\mathrm{T}_{3}\right)$ or without micronutrient $\quad\left(\mathrm{T}_{6}\right)$.Rapidly increased photosynthetic activities and translocation of more photosynthates in growing bulb with the application of micronutrients $(\mathrm{B}+\mathrm{Zn})$ might be the reason behind the increased length of the bulb. Application of $\mathrm{Zn}$ and $\mathrm{B}$ more or less increased the bulb diameter. The present findings were in agreement with the results of Samad et al., (2011), Trivedi and Dhumal (2013) and Manna (2013) in onion crop.

\section{Equatorial diameter of bulbs}

The result of equatorial diameter of bulbs revealed significant variations which ranged from minimum of $42.18 \mathrm{~mm}$ in $\mathrm{T}_{6}$ to maximum of $46.88 \mathrm{~mm}$ in $\mathrm{T}_{5}$ (Table 3 ). The marked improvement in size and diameter might be due to the translocation and storage of food materials from leaf to bulb for which micronutrients were the responsible factors. Zinc helped in translocation of constituents from one part to another part and boron also helped in the absorption of nitrogen and acted as a regulator of $\mathrm{Ca}: \mathrm{K}$ ratio in the plant. The micronutrient application especially boron which enhanced the enzyme activity which in turn triggered the physiological processes like protein and carbohydrate metabolism in plants. Similar findings were also reported by Shukla et al., (2015), Aske et al., (2017) in onion.

\section{Average bulb weight}

The maximum average weight $(61.72 \mathrm{~g})$ of bulb was significantly recorded in $\mathrm{T}_{5}$, i.e. foliar spray of micronutrients mixture @ 0.5 $\%(\mathrm{Fe}-2.5 \%, \mathrm{~B}-0.5 \%, \mathrm{Zn}-3 \%, \mathrm{Cu}-1 \%$ and $\mathrm{Mn}-1 \%$ ). The minimum average weight
$(50.73 \mathrm{~g})$ of bulb was observed in control plot $\left(\mathrm{T}_{6}\right)$ (Table 3).The supply of food is directly proportional to the rate of growth and development of bulb. Zinc rapidly increases the photosynthetic activity and translocation of photosynthates for growing onion bulbs and it influenced the bulb weight positively. Similar findings were also recorded by Mandal et al., (2003) in onion. Better efficacy of foliar application micronutrients viz., zinc and boron in onion was also reported by Acharya et al., (2015).

\section{Number of bulbs/kg}

The lowest number of bulbs (16.19)/kg was found in $\mathrm{T}_{5}$, i.e. foliar application of micronutrients mixture @ $0.5 \%(\mathrm{Fe}-2.5 \%$, $\mathrm{B}-0.5 \%, \mathrm{Zn}-3 \%, \mathrm{Cu}-1 \%$ and $\mathrm{Mn}-1 \%$ ) and it was at par with $\mathrm{T}_{3}$, i.e. soil application of Borax @ $10 \mathrm{~kg} / \mathrm{ha}$, while the highest number of bulbs (19.61)/kg was found in $\mathrm{T}_{6}$ (control) (Table 3). The less number of bulbs/kg was due to bigger size of bulbs.

\section{Yield parameters}

\section{Total Bulb yield/hectare}

Significant variation among the treatments for yield/hectare have been observed and varied from $214.78 \mathrm{q} / \mathrm{ha}$ in $\mathrm{T}_{6}$ to maximum of 266.80 $\mathrm{q} /$ ha in $\mathrm{T}_{5}$. Significantly highest yield/hectare $(266.80 \mathrm{q} / \mathrm{ha})$ was recorded in $\mathrm{T}_{5}$ i.e. foliar application of micronutrient mixture @ $0.5 \%$ (Fe - $2.5 \%, \mathrm{~B}-0.5 \%, \mathrm{Zn}-3 \%, \mathrm{Cu}-1 \%$ and $\mathrm{Mn}-1 \%$ ) followed by(250.18 q/ha) $\mathrm{T}_{4}$, i.e. foliar application of Borax @ $0.25 \%$. On the other hand, significantly the lowest bulb yield of $214.78 \mathrm{q} / \mathrm{ha}$ was recorded in control plot $\mathrm{T}_{6}$, i.e., without micronutrients application (Table 4).The higher photosynthesis accumulation in the bulbs would ensure higher individual bulb weight and large bulb diameter which collectively increases the bulb yield in onion. Similar reports of increased 
bulb yield was observed by several workers in onion (Abedin et al., 2012). The better efficacy of boron towards enhanced bulb yield was also observed by several research workers in onion (Manna, 2013). Similarly, the better efficiency of zinc towards increased bulb yield of onion were obtained by Alam et al., (2010) and Trivedi and Dhumal (2013).

\section{Marketable bulb yield/hectare}

The treatment $\mathrm{T}_{5}$, i.e. foliar application of micronutrient mixture @ $0.5 \%$ ( Fe - 2.5\%,B
$-0.5 \%, \mathrm{Zn}-3 \%, \mathrm{Cu}-1 \%$ and $\mathrm{Mn}-1 \%$ ) recorded maximum marketable bulb yield (260.45 q) per hectare followed by $\mathrm{T}_{4}$, i.e. foliar application of Borax @ $0.25 \%$ and $\mathrm{T}_{2}$, i.e. foliar application of Zinc sulphate @ 0.5 $\%$, where the marketable bulb yield were 242.95 and $233.88 \mathrm{q} / \mathrm{ha}$, respectively. However, significantly lowest bulb yield of $203.50 \mathrm{q} / \mathrm{ha}$ was recorded in control plot $\mathrm{T}_{6}$, i.e. without micronutrients application (Table 4).

Table.1 Methods adopted for determination of soil fertility status and total nutrient uptake by onion crop

\begin{tabular}{|c|c|c|c|}
\hline SI. No. & Property & Method adopted & Reference \\
\hline & \multicolumn{3}{|l|}{ A. Soil analysis } \\
\hline 1. & Available N $\left(\mathrm{kgha}^{-1}\right)$ & $\begin{array}{l}\text { Modified alkaline } \\
\text { permagnate }\end{array}$ & Subbiah and Asija (1956) \\
\hline 2. & Available P $\left(\mathrm{kg} \mathrm{ha}^{-1}\right)$ & $0.5 \mathrm{M} \mathrm{NaHCO} 3$ at $(\mathrm{pH} 8.5)$ & Olsen et al., (1954) \\
\hline 3. & Available $\mathrm{K}\left(\mathrm{kg} \mathrm{ha}^{-1}\right)$ & Flame photometry & Brown and Warncke (1988) \\
\hline 4. & Available sulphur $\left(\mathrm{mg} \mathrm{ha}^{-1}\right)$ & Turbidimetric & Tabatabai (1982) \\
\hline 5. & Available boron $\left(\mathrm{mg} \mathrm{ha}^{-1}\right)$ & $\begin{array}{l}\text { Hot water extractable } \\
\text { method }\end{array}$ & Berger and Trough (1939) \\
\hline 6. & Available zinc $\left(\mathrm{mg} \mathrm{ha}^{-1}\right)$ & DTPA extractable method & $\begin{array}{l}\text { Lindsay and Norvell } \\
\text { (1978) }\end{array}$ \\
\hline
\end{tabular}

Table.2 Effect of micronutrient on plant height $(\mathrm{cm})$ and number of leaves/plant of $\mathrm{rabi}$ onion

\begin{tabular}{|c|c|c|c|c|c|c|}
\hline & \multicolumn{3}{|c|}{ Plant height (cm) } & \multicolumn{3}{c|}{ Number of leaves/plant } \\
\cline { 2 - 7 } Treatments & 30 DAS & 60 DAS & 90 DAS & 30 DAS & 60 DAS & 90 DAS \\
\hline $\mathbf{T}_{\mathbf{1}}$ & 35.99 & 55.20 & 57.70 & 4.25 & 7.54 & 11.25 \\
\hline $\mathbf{T}_{\mathbf{2}}$ & 31.71 & 51.45 & 52.27 & 3.37 & 7.21 & 11.50 \\
\hline $\mathbf{T}_{\mathbf{3}}$ & 34.32 & 56.17 & 59.96 & 4.34 & 8.15 & 11.81 \\
\hline $\mathbf{T}_{\mathbf{4}}$ & 30.96 & 60.17 & 60.45 & 3.61 & 8.77 & 12.46 \\
\hline $\mathbf{T}_{\mathbf{5}}$ & 30.19 & 59.46 & 63.72 & 3.49 & 9.19 & 12.71 \\
\hline $\mathbf{T}_{\mathbf{6}}$ & 27.02 & 50.26 & 51.41 & 3.2 & 6.46 & 10.70 \\
\hline $\mathbf{S E}(\mathbf{d})$ & 0.338 & 0.599 & 0.612 & 0.072 & 0.098 & 0.084 \\
\hline $\mathbf{C D}$ at 5\% & 1.028 & 1.821 & 1.862 & 0.219 & 0.298 & 0.257 \\
\hline
\end{tabular}

$\mathrm{T}_{1}$ :Soil application of Zinc sulphate @ $10.0 \mathrm{~kg} / \mathrm{ha}, \mathrm{T}_{2}$ : Foliar application of Zinc sulphate @ $0.5 \%$ at 30 and 45 days after transplanting (DAT), $\mathrm{T}_{3}$ : Soil application of Borax @ $10.0 \mathrm{~kg} / \mathrm{ha}, \mathrm{T}_{4}$ : Foliar application of Borax @ $0.25 \%$ at 30 and 45 DAT, $\mathrm{T}_{5}$ : Foliar application of micronutrient mixture @ $0.5 \%$ at 30 and 45 DAT, $\mathrm{T}_{6}$ : Control 
Table.3 Effect of micronutrients on neck thickness $(\mathrm{cm})$, polar and equatorial bulb diameter $(\mathrm{mm})$, average bulb weight $(\mathrm{g})$ and number of bulbs/kg

\begin{tabular}{|c|c|c|c|c|c|}
\hline Treatments & $\begin{array}{c}\text { Neck } \\
\text { thickness } \\
\text { (cm) }\end{array}$ & $\begin{array}{c}\text { Polar } \\
\text { diameter of } \\
\text { bulb } \mathbf{( m m})\end{array}$ & $\begin{array}{c}\text { Equatorial } \\
\text { diameter of } \\
\text { bulb } \mathbf{( m m})\end{array}$ & $\begin{array}{c}\text { Average bulb } \\
\text { weight }(\mathbf{g})\end{array}$ & $\begin{array}{c}\text { Number of } \\
\text { bulb/kg }\end{array}$ \\
\hline $\mathbf{T}_{\mathbf{1}}$ & 0.81 & 52.22 & 45.53 & 54.56 & 18.29 \\
\hline $\mathbf{T}_{\mathbf{2}}$ & 0.60 & 55.05 & 46.63 & 56.35 & 17.74 \\
\hline $\mathbf{T}_{\mathbf{3}}$ & 0.68 & 53.75 & 45.44 & 55.69 & 17.93 \\
\hline $\mathbf{T}_{\mathbf{4}}$ & 0.71 & 55.25 & 46.73 & 59.38 & 16.87 \\
\hline $\mathbf{T}_{\mathbf{5}}$ & 0.66 & 58.62 & 46.88 & 61.72 & 16.19 \\
\hline $\mathbf{T}_{\mathbf{6}}$ & 0.92 & 48.67 & 42.18 & 50.73 & 19.61 \\
\hline $\mathbf{S E}(\mathbf{d})$ & 0.009 & 1.217 & 0.447 & 0.633 & 0.192 \\
\hline $\mathbf{C D} \mathbf{a t} \mathbf{5 \%}$ & 0.026 & 3.702 & 1.359 & 1.927 & 0.584 \\
\hline
\end{tabular}

$\mathrm{T}_{1}$ :Soil application of Zinc sulphate @ $10.0 \mathrm{~kg} / \mathrm{ha}, \mathrm{T}_{2}$ : Foliar application of Zinc sulphate @ $0.5 \%$ at 30 and 45 days after transplanting (DAT), $\mathrm{T}_{3}$ : Soil application of Borax @ $10.0 \mathrm{~kg} / \mathrm{ha}, \mathrm{T}_{4}$ : Foliar application of Borax @ $0.25 \%$ at 30 and 45 DAT, $\mathrm{T}_{5}$ : Foliar application of micronutrient mixture @ $0.5 \%$ at 30 and $45 \mathrm{DAT} \mathrm{T}_{6}$ : Control

Table 4.Effect of foliar application of micronutrients on yield and marketable bulb yield in onion and $\mathrm{B}: \mathrm{C}$ ratio

\begin{tabular}{|c|c|c|c|}
\hline Treatments & $\begin{array}{c}\text { Bulb yield/hectare } \\
(\mathbf{q} / \mathbf{h a})\end{array}$ & $\begin{array}{c}\text { Marketable bulb } \\
\text { yield/hectare } \\
(\mathbf{q} / \mathbf{h a})\end{array}$ & B:C ratio \\
\hline $\mathbf{T}_{\mathbf{1}}$ & 228.30 & 218.06 & 3.49 \\
\hline $\mathbf{T}_{\mathbf{2}}$ & 233.30 & 223.88 & 3.42 \\
\hline $\mathbf{T}_{\mathbf{3}}$ & 219.27 & 207.69 & 2.93 \\
\hline $\mathbf{T}_{\mathbf{4}}$ & 250.18 & 242.95 & 3.92 \\
\hline $\mathbf{T}_{\mathbf{5}}$ & 266.80 & 260.45 & 4.61 \\
\hline $\mathbf{T}_{\mathbf{6}}$ & 214.78 & 203.50 & 4.08 \\
\hline $\mathbf{S E}(\mathbf{d})$ & 1.830 & 2.009 & - \\
\hline $\mathbf{C D}$ at 5\% & 5.568 & 6.111 & - \\
\hline
\end{tabular}

$\mathrm{T}_{1}$ :Soil application of Zinc sulphate @ $10.0 \mathrm{~kg} / \mathrm{ha}, \mathrm{T}_{2}$ : Foliar application of Zinc sulphate @ $0.5 \%$ at 30 and 45 days after transplanting (DAT), $\mathrm{T}_{3}$ : Soil application of Borax @ $10.0 \mathrm{~kg} / \mathrm{ha}, \mathrm{T}_{4}$ : Foliar application of Borax @ $0.25 \%$ at 30 and 45 DAT, $\mathrm{T}_{5}$ : Foliar application of micronutrient mixture @ $0.5 \%$ at 30 and $45 \mathrm{DAT}_{1} \mathrm{~T}_{6}$ : Control 
Table 5.Effect of micronutrients on production of A, B and C grade bulbs in onion cv. Sukhsagar

\begin{tabular}{|c|c|c|c|}
\hline & A grade bulb(\%) & B grade bulb (\%) & C grade bulb (\%) \\
\hline Treatments & 14.57 & 25.39 & 23.24 \\
\hline $\mathbf{T}_{\mathbf{1}}$ & 20.01 & 28.07 & 25.69 \\
\hline $\mathbf{T}_{\mathbf{2}}$ & 15.54 & 23.955 & 27.77 \\
\hline $\mathbf{T}_{\mathbf{3}}$ & 23.03 & 25.403 & 21.07 \\
\hline $\mathbf{T}_{\mathbf{4}}$ & 29.82 & 27.64 & 18.99 \\
\hline $\mathbf{T}_{\mathbf{5}}$ & 8.27 & 16.208 & 35.1 \\
\hline $\mathbf{T}_{\mathbf{6}}$ & 0.256 & 0.472 & 0.387 \\
\hline $\mathbf{S E}(\mathbf{d})$ & 0.78 & 1.177 & 1.177 \\
\hline $\mathbf{C D}$ at 5\% & & \\
\hline
\end{tabular}

$\mathrm{T}_{1}$ :Soil application of Zinc sulphate @ $10.0 \mathrm{~kg} / \mathrm{ha}, \mathrm{T}_{2}$ : Foliar application of Zinc sulphate @ $0.5 \%$ at 30 and 45 days after transplanting (DAT), $\mathrm{T}_{3}$ : Soil application of Borax @ $10.0 \mathrm{~kg} / \mathrm{ha}, \mathrm{T}_{4}$ : Foliar application of Borax @ $0.25 \%$ at 30 and 45 DAT, $\mathrm{T}_{5}$ : Foliar application of micronutrient mixture @ $0.5 \%$ at 30 and 45 DAT, $\mathrm{T}_{6}$ : Control

The higher yield might be due to increase in plant height, number of leaves, and yield attributes viz., polar and equatorial diameter of bulb, higher individual average bulb weight. The result also showed significantly better efficacy of foliar application of micronutrients over soil application, which might be due to better utilization of applied nutrients which required in minute quantities by foliar spray rather than soil application. A similar result of better efficacy of foliar sprays over soil application of micronutrient was reported by Acharya et al., (2015) in multiplier onion.

\section{Production of A, B and C grade bulbs}

The $\%$ of production of $\mathrm{A}$ grade bulbs varied significantly among different treatments ranging from minimum of 8.27 in control $\left(\mathrm{T}_{6}\right)$ to maximum of 29.82 in $\mathrm{T}_{5}$. Significantly highest \% of A grade bulbs were obtained by plot of treatment $\mathrm{T}_{5}$ i.e. foliar application of micronutrient mixture @ $0.5 \%$ ( $\mathrm{Fe}-2.5 \%$, B $-0.5 \%, \mathrm{Zn}-3 \%, \mathrm{Cu}-1 \%$ and $\mathrm{Mn}-1 \%)$ closely followed by $\mathrm{T}_{4}$ (foliar application of Borax @ $0.25 \%)$. Similarly, the \% of production of $\mathrm{B}$ grade bulbs varied from $16.20\left(\mathrm{~T}_{6}\right)$ to $28.07\left(\mathrm{~T}_{2}\right)$.Foliar application of
Zinc sulphate @ $0.5 \%$ recorded significantly highest \% of B grade bulbs (28.07).The \% of production of $\mathrm{C}$ grade bulbs, varied from minimum of $18.99\left(\mathrm{~T}_{5}\right)$ to maximum 35.10 $\left(\mathrm{T}_{6}\right)$. Foliar application of micronutrient mixture $\left(\mathrm{T}_{5}\right)$ recorded minimum $\%$ of $\mathrm{C}$ grade bulbs. The overall results on production of $\mathrm{A}$ and $\mathrm{B}$ grade bulbs indicate that application of micronutrients (both soil and foliar) increased the $\%$ of superior graded bulbs as compared to control treatment. Significantly maximum $\%$ of $\mathrm{A}$ and $\mathrm{B}$ grade bulbs were produced in the promising treatments might be due to significantly higher polar and equatorial diameter due to application of micronutrients.

In conclusion, the highest values for plant growth characters viz. Plant height (63.72 $\mathrm{cm}$ ), number of leaves/plant (12.71) were recorded with the foliar application of $0.5 \%$ micronutrient mixture (Fe - $2.5 \%, \mathrm{~B}-0.5 \%$, $\mathrm{Zn}-3 \%, \mathrm{Cu}-1 \%$ and $\mathrm{Mn}-1 \%)\left(\mathrm{T}_{5}\right)$. However, among the micronutrient treatments the next best values with respect to plant height $(60.45 \mathrm{~cm})$ and number of leaves/plant (12.46)were recorded with the foliar application of $0.25 \%$ borax $\left(\mathrm{T}_{4}\right)$. The bulb characters viz. neck thickness $(0.60 \mathrm{~cm})$ i.e. relatively thin was observed in soil 
application of zinc sulphate @ $10 \mathrm{~kg} / \mathrm{ha}\left(\mathrm{T}_{1}\right)$ closely followed by foliar application of 0.5 $\%$ micronutrient mixture (Fe $-2.5 \%, \mathrm{~B}-0.5$ $\%, \mathrm{Zn}-3 \%, \mathrm{Cu}-1 \%$ and $\mathrm{Mn}-1 \%)\left(\mathrm{T}_{5}\right)$ $(0.66 \mathrm{~cm})$. The maximum polar diameter $(58.62 \mathrm{~mm})$, equatorial diameter of bulb $(46.88 \mathrm{~mm})$ and average weight of bulb $(61.72 \mathrm{~g})$ were recorded with the foliar application of $0.5 \%$ micronutrient mixture (Fe $-2.5 \%, \mathrm{~B}-0.5 \%, \mathrm{Zn}-3 \%, \mathrm{Cu}-1 \%$ and $\mathrm{Mn}-1 \%)\left(\mathrm{T}_{5}\right)$. The lowest number of bulbs/ $\mathrm{kg}$ (17.74) was found in $\mathrm{T}_{2}$ i.e. foliar application of zinc sulphate. The yield characters viz., maximum yield/plot $(8.01 \mathrm{~kg})$, yield/hectare $(266.80 \mathrm{q} / \mathrm{ha})$, highest $\%$ of $\mathrm{A}$ grade bulbs $(29.82 \%)$, minimum $\%$ of $\mathrm{C}$ grade bulbs (18.99\%)were recorded with the foliar application of $0.5 \%$ micronutrient mixture (Fe - $2.5 \%, \mathrm{~B}-0.5 \%, \mathrm{Zn}-3 \%, \mathrm{Cu}-$ $1 \%$ and $\mathrm{Mn}-1 \%)\left(\mathrm{T}_{5}\right)$. However, foliar application of zinc sulphate recorded significantly highest $\%$ of $\mathrm{B}$ grade bulbs $(28.07 \%)$. Hence, from the present study it can be concluded that among all the micronutrient treatment schedule, it was observed that the treatment schedule, $\mathrm{T}_{5}$ i.e., foliar spray of micronutrients mixture (iron$2.5 \%$, boron- $0.5 \%$, zinc- $3 \%$, copper- $1 \%$ and manganese-1\%)@0.5\% at 30 and 45 DAP significantly recorded better results on almost all parameters under study than rest of the treatments.

\section{References}

Abedin, M.J., Alam, M.N., Hossain, M.J., Ara, N.A. and Haque K.M.F. 2012. Effect of micronutrients on growth and yield of onion under calcareous soil environment. International Journal of Biosciences. 2(8): 95101.

Acharya, U., Venkatesan, K., Saraswathi, T. and Subramanian, K. S. 2015.Effect of Zinc and Boron Application on Growth and Yield Parameters of Multiplier Onion (Allium cepa L. var aggregatum Don.) var. CO (On) 5. International Journal of Research. 2(1): 757765.
Alam, M.N., Abedin, M.J. and Azad, M.A.K. 2010. Effect of micronutrients on growth and yield of onion under calcareous soil environment. International Research Journal of Plant Science. 1(3): 056-061.

Anonymous. Horticultural Statistics At A Glance. 2017. Horticulture Statistics Division; Department of Agriculture, Cooperation \& Farmers Welfare; Ministry of Agriculture \& Farmers Welfare; Government of India. pp.209-210.

Aske, V., Jain, P.K., Lal, N. and Shiurkar, G. 2017. Effects of Micronutrients on Yield, Quality and Storability of Onion cv. Bhima Super. Trends in Biosciences. 10(6): 13541358.

Ballabh, K., Rana, D.K. and Rawat, S.S. 2013. Effects of foliar application of micronutrients on growth, yield and quality of onion. Indian Journal of Horticulture. 70(2): 260-265.

Berger, K.C. and Troug, E. 1939.Boron determination in soils and plants. Industrial and Engineering Chemistry. Analytical Edition.11: 540-545.

Bhonde, S.R.L., Ram, U.B., Pandey, Tiwari, H.N. 1995. Effect of micronutrients on growth, yield and quality of kharif onion. Newsletter National Horticulture Research and Development Foundation. 14-15(1):16-20.

Brady, N. C. In: The nature and properties and soils. 10th edition, A. K. Ghosh. Printing Hall of India Pvt. Ltd., New Delhi. 1990; pp. 383.

Brown, A.J. and Warncke, D. 1988. Recommended cation tests and measures of cation exchange capacity. In: Recommended Chemical Soil Tests Procedures for the North Central Region, ed. W.C. Dahnke, Bulletin No. 499 (Revised), North Dakota Agricultural Experiment Station, Fargo, North Dakota. pp.15-16.

Dake, S.D., Hiwale, B.G., Patil, V.K. and Naik, P.G. 2011.Effect of micronutrients on growth, yield and quality of onion (Allium cepa L.) cv. Baswant 780. In. Proceeding of National Symposium on Alliums: Current Scenario and Emerging Trends, Pune, India. pp. 205.

Goyal, R., Uike, V. and Verma, H. 2017. Effect of foliar application of micronutrients on growth and yield of onion (Allium cepa L.) c.v. Agri found dark red. Agricultural Science Digest. 37(2): 160-162. 
Kolota, E. and Osinsk, M. 2001. Efficiency of foliar nutrition of field vegetables grown at different nitrogen rates. Acta Horticulturae. 563: 87-91.

Mandal, S., Nath, S., Ghanji, P. and Sukala, N. 2011. Effect of doses and methods of application of GA3 and NAA on growth and yield of onion (Allium cepa L.).Environment and Ecology. 21(3): 568-571.

Manna, D. 2013. Growth, yield and bulb quality of onion (Allium cepa L.) in response to foliar application of boron and zinc. SASRC Journal Agriculture. 11(1):149-153.

Maurya, P. K., Yadav, L. M., Thakur, G. and Patel, P. 2018. Effect of Micronutrient Application on Growth and Yield of Kharif Onion (Allium cepa L.). International Journal of Current Microbiology and Applied Sciences. 7(03):601-608.

Mishra, P., Sarkar, C., Viswajith, K. P., Dhekale, B. S. and Sahu, P. K. 2013.Instability and forecasting using ARIMA model in aua, Production and productivity of onion in India. Journal of Crop and Weed. 9:96-01.

Olsen, S. P., Coles, C. V., Watanabe and Dean, L. A. 1954. Estimation of available phosphorus in soil by extraction with sodium bicarbonate. USDA Circular -939.

Patil, V. K., Yadlod, S.S., Tambe, T.B. and Narsude, P.B. 2009. Effect of foliar application of micronutrients on flowering and fruit set of tomato (Lycopersicon esculentum Mill) cv. Phule raja. International Journal of Agricultural Sciences. 6(10): 164-166.

Paul, J.K., Halder, B.C. and Khan, M.A. 2007. Effects of boron and sulphur on the growth and yield of onion. Journal of Science and technology. 5: 60-66.

Pramanik, K., Tripathy, P., Mandal, P., Pradhan, M. and Biswal, M. 2018. Effect of micronutrients on quality of onion (Allium cepa L.). International Journal of Chemical Studies. 6(6): 1324-1327.

Rashid, M.H.A., Massiah, A.J. and Thomas, B. 2016. Genetic regulation of day length adaptation and bulb formation in onion (Allium cepa L.). Acta Horticulturae. 1143: 714.

Samad, A.E., Khalifa, R.K.M., Lashine, Z.A. and Shafeek, M.R. 2011. Influence of urea fertilization and foliar application of some micronutrients on growth, yield and bulb quality of onion. Australian Journal of Basic Applied Sciences. 5(5): 96-103.

Shukla, L., Bose, U.S. and Ahirwar, M.K. 2015.Effect of foliar feeding of micronutrients on growth, yield and income from rabi onion var. Agrifound Light Red. Annals of Plant and Soil Research. 17(3): 307-310.

Smiriti, S., Kumar, R. and Singh, S.K. 2002.Effect of sulphur and boron nutrition on growth, yield and quality of onion (Allium cepa L.) Patna. Indian Journal of Applied Biology. 12(1/2): 40-46.

Subbiah, B. and Asija, G. L. 1956. A rapid procedure for estimation of available nitrogen in soils. Current Sciences. 25: 259-260.

Tabatabai, M. A. 1982. Sulfur. In Methods of Soil. buy sis, Part 2 (A. L. Page, Ed.), ilgronomr 9, 501-538.

Tisdale, S. L, Nelson, W.L. and Beaton, J.D. 1984. In: Soil Fertility and Fertilizers. 4th Edition. Mac Millan Publication Company. New York. pp. 285.

Trivedi, A. P, and Dhumal, K. N. 2013. Effect of soil and foliar applications of zinc and iron on the yield and quality of onion (Allium cepa L.). Bangladesh Journal of Agricultural Research. 38(1): 41-48.

\section{How to cite this article:}

Pooja Biswas, Shreya Das, Aloke Bar, Tapan Kumar Maity and Amit Ranjan Mandal. 2020. Effect of Micronutrient Application on Vegetative Growth and Bulb Yield Attributes of Rabi Onion (Allium cepa L.). Int.J.Curr.Microbiol.App.Sci. 9(03): 556-565. doi: https://doi.org/10.20546/ijcmas.2020.903.065 